\title{
The Impact of Military Engagement in Disaster Management on Civil- Military Relations
}

Marjan Malešič ${ }^{1}$

\begin{abstract}
The frequency, scope, and intensity of natural disasters are increasing, and so too are the number of victims, related deaths, and the amount of economic damage. The increasing frequency of disasters often overwhelms civilian management structures and demands the engagement of the military. This has generated new problems and controversies. However, mainstream scholarship in this field has so far failed adequately to address civil-military relations in disaster management. This article highlights the issue and addresses the various arguments used to advocate or reject military involvement in disaster management: militarisation, utilitarian, security-strategic, functional-humanitarian, and rejection-isolation arguments. This epistemological and ontological approach identifies, depicts, and classifies the arguments. It also identifies the various controversies that accompany military engagement in disaster management as a basis for future research into civil-military relations in the field.
\end{abstract}

\section{Keywords:}

Civil-military relations, disaster management, disaster, military, arguments

This is a post-print (Version 2) of the article, which was originally published in Current Sociology. 2015. Vol. 63(7) 980-998 by SAGE Publications Ltd. The publisher's version of this article is available at http://dx.doi.org/10.1177/0011392115577839.

Suggested citation:

Malešič, Marjan. 2015. The impact of military engagement in disaster management on civilmilitary relations. Current Sociology 63 (7):980-998. doi: 10.1177/0011392115577839.

\footnotetext{
${ }^{1}$ Faculty of Social Sciences, University of Ljubljana, Slovenia
} 


\section{Introduction}

Natural disasters represent one of the most evident threats to humanity, all the more so as a result of climate change. Nevertheless, natural disasters have received relatively modest attention in debates on national and international security. The Centre for Research on the Epidemiology of Disasters (CRED) regularly reports natural disaster statistics on a global level. In the decade from 2002-2011 the average annual disaster frequency was 394 cases $^{\mathrm{i}}$. The average annual number of deaths from disasters was 107,000; the total number of victims 268 million, and the economic damage was estimated at \$143 billion. The geographical distribution of disasters over the last decade indicates that Asia is the most affected region, followed by the Americas, Europe, Africa, and Oceania. In terms of countries, China, the United States, the Philippines, India, and Indonesia constitute the top five most frequently hit by natural disasters (CRED, 2013: 1, 2).

The data reveals that natural and non-natural disasters represent a major threat to national and international security. Countries and international organisations have developed structures to respond to disasters, although the quality of those structures varies from country to country and from one international organisation to another. As a rule, developing countries tend to lack comprehensive and stable civilian structures for dealing with disasters, therefore disaster response in developing countries often relies almost entirely upon the military as well as on international civilian and military assistance. In developed countries, civilian disaster response structures exist and operate at relatively high levels; nevertheless, in the event of a major disaster, the military may be called upon to provide assistance to the civilian structures; while international organisations also often collaborate in the response. ${ }^{\text {ii }}$

Since the turn of the millennium, the frequency, scope, and intensity of disasters have increased. Some disasters exceed the available civilian capabilities and require the engagement of military equipment and personnel to save lives and protect property. As a result, the role of the military 
in disaster management and in civilian crisis management in general has become a topic for debate.

The recent literature on disaster management (see for example Weeks, 2007, SIPRI, 2008, Barber, 2009, Marret, 2009, Arcala Hall and Cular, 2010, Kapucu, 2011, Ferris 2012, Briggs, 2012, Mamuji, 2012, Tatham et. al., 2012) focuses on military engagement in disaster response and covers themes such as: the legal issues; civil-military cooperation; the effectiveness of military assistance in responding to a disaster; the problem of leadership; coordination; divergent civil and military organisational cultures; and the public's perception of military assistance. By comparison, our article predominantly focuses on the content and frequency of the various arguments that have been advanced about military engagement in disaster response, and on their impact on civil-military relations.

Conventional theories of civil-military relations have so far paid little attention to this issue. It is clear that a disaster which requires the armed forces to work alongside civilian rescue and search teams, the general public, political decision-makers and humanitarian organisations represents opportunities for a unique civil-military interface. This can foster cooperation and a mutual transfer of values. Alternatively, it may result in competition, conflict, and a clash of organisational cultures. These ideas are not new, but have become more significant given the advances in civil-military relations. The opportunity is even greater when one takes into account the statistical frequencies and intensities of the disasters depicted above, and the ever greater presence of the military in disaster management, which highlights the need for further studies on civil-military relationships. ${ }^{\text {iii }}$

A brief review of the recent scientific articles and books in the field of civil-military relations suggests that most authors still predominantly base their analyses on the traditional works, namely either Huntington's 'The Soldier and the State' (1957), or of Janowitz's 'The Professional Soldier' (1960). As suggested by Croissant and Kuehn (2011: 131), Huntington 
and Janowitz produced a bifurcation in civil-military research into a political science strand and a sociological strand. The latter predominantly studied topics such as the bureaucratic organisation of the military, military families, sexual, racial, minority and gender integration into the military, public opinion of the military and alike; whereas the former were mostly concerned with political control of the armed forces, the subordination of the military to the legitimate civilian leadership, military professionalism, the 'management of violence', and so forth. We investigated several concepts, such as the military as internally structured phenomenon (Segal et al. 1974), new military professionalism (Sarkesian, 1981), the military's distinctive organisational culture (Boëne, 1990), the idea of a postmodern military (Moskos, 2000), the key dimensions of civil-military relations (Dandeker, 2000), and the 'culture gap' (Feaver and Kohn, 2001). We also analysed other concepts that emphasise that the civilmilitary concept is broader in its nature, as a result of which the 'civilian' component can be divided into those civilians who represent the authorities and those who comprise the general public (Cohn, 2003). Thus, on one hand, civil-military relations can refer to the interface between the military and the political establishment, and on the other hand to the relationship between the military and civilian society (Pinch, 2003).

Nielsen (2012: 369) has summarised the current American approach to civil-military relations and has established that Huntington's work remains the essential starting point for discussion, despite the profound social and strategic changes that have taken place in society, and despite the active research of political scientists, sociologists and historians in the field. Although some of them have criticised Huntington, none of them have yet transcended his work. This observation is somewhat contentious given the fact that several scholars (including those mentioned above) have followed in the tradition of Janowitz in promoting the sociological strand of civil-military relations.

A similar review of the European scene reveals that there have been attempts to introduce political science innovations into the field of civil-military relations (Croissant and Kuehn, 
2011: 132). These attempts extend beyond 'civilian control of the military' and deal with the influence of parliaments, the media, the public and broader civil society and their impact on civil-military relations. New concepts of 'democratic control of the military' (Born et al., 2004) and 'security sector governance' (Hängi, 2004) have been introduced which have also advocated methodological pluralism and have tried to overcome the traditional positivist epistemology of civil-military relations. ${ }^{\text {iv }}$

Therefore civil-military relations extend far beyond the relationship between the military and the civilian authorities. It also involves civil society as a significant actor. It is interesting to observe that those analysts who follow in the Huntington tradition of the functional and social imperative and who want to transcend it do not recognise disaster management as one of the important fields in which civil-military relations occur. Moreover, in several countries disaster management is an important military duty, not only in terms of public perception but in practice as well. $^{\mathrm{v}}$

The intention of this article is to help refocus the debate, although we recognise that there are several dimensions of civil-military relations in the disaster management process. Rather than attempting to address them all here, we will instead scrutinise the nature of the pro and contra arguments and their motivation. In our view, the knowledge of the arguments and the motivation behind them is crucial for understanding civil-military relations in disaster management, and this creates a solid basis for future research that could specifically focus on the various characteristics of civil-military relations in disaster management.

This article is an epistemological and ontological attempt to identify, to depict and to classify the various arguments that are implicit in the theoretical considerations of the role of the military in disaster management. Our primary method is an analysis of the discourse that goes beyond the positivist approach and attempts to find answers to research questions in the constructivist 
mode. Our approach is concerned with the broader context of civil-military relations and takes into account the various influences and practices (comp. Freistein, 2011:

167). Disaster management is a subject to be studied in the context of civil-military relations. We will focus on the following research questions: (1) What are the main theoretical arguments for military engagement in disaster response, and which of them have been confirmed in practice by recent global events? (2) Do the nature of those arguments and their justifications predict the characteristics of civil-military relations in disaster management? In order to answer these questions, we will first explore the theory of military collaboration in disaster response and attempt to identify, depict, and classify the key arguments used. We will then perform a secondary analysis of the recent scientific and professional reports on disaster response in order to confirm the presence of the various arguments and assess their explanatory power as applied to recent disaster cases. And finally, we will estimate the potential impact of these arguments on the characteristics of civil-military relations, and suggest where future research in the field would prove beneficial.

\section{The Military in the Disaster Response Process}

The theoretical discourse on the role of the military in the process of disaster management (e.g. Perry and Travayiakis, 2007, Amudson et al., 2008, Brattberg, 2013) suggests that countries offer military assistance to affected countries and their population due to the benefits they receive from offering assistance. For instance, offering assistance may improve their global image, particularly within those countries to which they extend their help. Armitage and Nye (2008) claim that, by collaborating in disaster management, armed forces have on many occasions proved that they can generate soft power for their countries. Hence, disaster assistance becomes an important diplomatic activity. ${ }^{\mathrm{vi}}$

Some authors (Tritten, 2013, Arcala Hall, 2008) believe that military disaster response in foreign countries can also promote positive security effects by improving the securitystrategic position of donor countries, while at the same time disaster assistance might have a favourable 
impact on regional security relations, especially in those areas of the world that are disasterprone (e.g. parts of Asia).

Also important is Hoffman and Hudson's (2009: 1) observation that military involvement in disaster management is driven by the military's own concern to improve its public image, to use disaster response as a form of training, and to diversify military role in times of austerity and military budget cuts. Consequently, there is a growing interest in official circles in the US and the EU in deploying civil defence and military assets outside their home territories. This has generated a few concerns in light of the fact that a military presence in a humanitarian mission could, especially in a conflict environment, compromise the neutrality and the independence of humanitarian organisations, and could restrict humanitarian access and actually increase security risks. Some even argue, as Hoffman and Hudson note (2009: 2), that military involvement in humanitarian relief is 'inefficient, inappropriate, inadequate and expensive, contrary to humanitarian principles, and driven by political imperatives rather than humanitarian need.'

Hoffman and Hudson (2009: 2) maintain that, despite the criticism, many humanitarian actors accept the idea that the military can play a legitimate and vital role in supporting humanitarian relief efforts. The argument is that humanitarian organisations should engage more strategically with military organisations in order to overcome the possible risks that may arise from civilmilitary cooperation, and to reinforce the potential benefits that military involvement could bring to the affected population. Marret (2009: 339) appears to agree, noting that one part of the humanitarian community remains sceptical and critical of the role of the military in humanitarian affairs which they perceive as 'militarised humanitarianism.' Nevertheless, there is another part of the humanitarian community that recognises the successes as well as the inadequacies of the military response to humanitarian challenges. 
Similarly, Etkin et al. (2014: 11-12) have identified two divergent perspectives on the role of military assets in the disaster relief process: one that is supportive of 'militarisation' and requires a greater military presence; the other is critical of a military approach to managing disasters. Etkin et al. (2014: 26-27) conclude that the military forces of democratic nations can make a major contribution to disaster relief; nevertheless, military assets should be selectively and adequately employed to supplement as opposed to replace civilian disaster management authorities and assets. The involvement of the military in the disaster management matrix would be efficient if the military commanders planned and coordinated together with civilian authorities, and if civilian and military actors were able to overcome the difficulties that stem from their different cultures.

Desch (quoted by Arcala Hall and Cular, 2010: 62) believes that, due to its transitional nature and strict time limitations, disaster relief is relatively uncontroversial compared to other types of domestic military missions. In a democracy, it does not threaten the civil-military power balance. Mandel (quoted by Arcala Hall and Cular, 2010: 64, 65) warns of the dangers of militarising the relief process. Instead, he advocates a more targeted deployment of the better equipped and mobile military units, confined to those instances where the more modest civilian relief organisations and NGOs lack such capacity.

Some authors stress that there are several potential pitfalls to military humanitarian assistance and disaster relief that need to be taken into account. Laksmana (2010), for example, warns that military resources are suitable only for high-intensity, short-term missions, and not for longterm engagements of several weeks or months. The latter might divert the military from their traditional mission of 'violence management'. Furthermore, humanitarian assistance and disaster relief require different training and equipment than traditional military tasks. In terms of their organisational culture and ethos, humanitarian assistance and disaster relief missions are required to respect humanitarian principles; they also require patience, restraint, and flexibility. Laksmana (2010) also highlights a few other important issues, including: the 
influence of humanitarian assistance and disaster relief on civil-military relations; the dependence of civilian structures on military capabilities; and, consequently, the militarisation of civilian functions in disaster management.

This also raises the question of military disaster relief: 'at what point in the spectrum of support does assistance become interference?' (Civil-Military Relations in Disaster Response). Meanwhile, from the military perspective, some commanders may be concerned that providing disaster relief becomes a distraction from their primary mission, namely the defence of their own country. Other military leaders regard humanitarian support as an appropriate duty that advances their nation's overall policy objectives, and therefore are more readily accepting of deployment to complex crises in order to minimise casualties.

The role of the military in disaster management and the nature of civil-military relations are also discussed in the context of the human security concept (Futamura et al., 2011). Futamura et al believe that, in civil conflicts, the military may sometimes be the primary threat to human security. Whereas, in the case of disasters, the military's operational capacities and experience of working in the field means that it may become the crucial guarantor of human security.

Any discussion of civil-military relations also needs to address the public's acceptance of the support role played by the military in disasters. The Intertect Study (1989) established an association between disaster relief and military involvement in the public's view: the public expect military units to assist the civilian population immediately following a large-scale disaster. From the public's perspective, this is a humanitarian act; from the military perspective, this represents an opportunity to strengthen its legitimacy in civil society.

Fisher (2011) reports that many experts, influenced by the experiences of complex disasters, have advocated that humanitarian relief should become one of the core and standardised tasks of a modern army. This proposal assumes that civilian authorities are often overwhelmed by huge disasters and therefore military assistance is a rational choice. Therefore, disaster relief 
should be 'the main part of military business, not simply a secondary task'. On the other hand, there is considerable disagreement among government agencies and humanitarian organisations as to whether the benefits of military assistance outweigh the costs. The benefits might be said to include: unique military capabilities, transport, logistics, medical equipment, and timely rapid deployment. Meanwhile, the costs are variously said to include: the financial costs, the risk of militarising relief work and potential security concerns, especially when the military operates in a foreign country.

\section{The Content of Theoretical Arguments}

The abstract view of the theoretical considerations concerning military engagement in disaster response clearly demonstrates several types of argument which we could label 'utilitarian', 'security-strategic', 'militarisation', 'functional-humanitarian', and 'rejection-isolation' arguments (see Table 1).

Table1: Classification of Arguments

\begin{tabular}{|l|l|}
\hline Utilitarian argument & $\begin{array}{l}\text { strategic national interests, } \\
\text { the public image of the deploying country, } \\
\text { the political and economic benefits, } \\
\text { the public image of the military and its legitimacy in } \\
\text { society, }\end{array}$ \\
\hline Security-strategic argument & $\begin{array}{l}\text { the security position of deploying country, } \\
\text { relations with allies, } \\
\text { military disaster management as a soft power, } \\
\text { the contribution to human security, } \\
\text { military operational gains, } \\
\text { the variety of military roles, } \\
\text { the diversity of training and the higher morale } \\
\text { of staff }\end{array}$ \\
\hline
\end{tabular}




\begin{tabular}{|l|l|}
\hline Militarisation argument & $\begin{array}{l}\text { military presence in disaster management, } \\
\text { military assistance as a first or last resort, } \\
\text { militarising effects } \\
\text { the centralisation of disaster response }\end{array}$ \\
\hline Functional-humanitarian argument & $\begin{array}{l}\text { the military in overcoming disaster consequences, } \\
\text { the population and authorities need assistance, }\end{array}$ \\
the capabilities of the military in terms of personnel, \\
equipment, and the expertise to help people in need
\end{tabular}

Source: the author

The utilitarian argument emphasises the benefits to the deploying country by engaging its troops on disaster sites in a foreign country. There is an expectation on the part of the sending country that their image in the world will improve, that they may realise certain national strategic interests, and that they stand to make diplomatic, trade, and security gains. Also, the country will be able to promote its overall policy objectives by collaborating in disaster management. When it comes to military disaster response within a national framework, politicians and military commanders both expect to be able to observe an improvement in the image and prestige of the military among the public, and that the military's legitimacy in society will increase. There is also a cost-benefit analysis behind this argument: the benefits to the military far outweigh the costs involved. Military assistance in a disaster is arguably predominantly motivated by political reasons; humanitarian motivations are only of secondary importance. 
Closely related to the utilitarian argument is the security-strategic argument that assesses how a military disaster response may influence the security and strategic position of the sending country both in the receiving country and in the wider region. This argument holds that international military assistance tends to promote better relations with allies and to strengthen the position of the country in the regional security milieu. The engagement of the military in disaster management is also seen as a form of soft power implementation in that the political influence of the country abroad expands as a consequence. By collaborating in disaster management, the military contributes to the reinforcement of human security. Responding to a disaster also promises potential operational gains, such as a diversification of military roles, various modes of training, and a higher morale among staff.

The militarisation argument is critical of the increasingly militarised response to disasters. The military's role in resolving the disaster scenario should be a last resort. Instead, it is often regarded as the first choice. This argument criticises the formation of special disaster management military units, their plans, training, and assets that might dominate the process. Some claim that governments misuse disasters in order to justify granting the military a greater role in civilian affairs in general. They assume that by deploying the military in disaster response, civil society relief organisations may become militarised. The presence of the military at a disaster site ipso facto jeopardise the core principles that guide the work of international humanitarian agencies and NGOs, i.e. neutrality, impartiality, and independence. The militarisation argument is sometimes accompanied by a centralisation thesis which claims that, by engaging the military, the country is assuming responsibility for disaster management to the detriment of other territorial-political communities, i.e. municipalities, regions, and federal states, respectively.

The functional-humanitarian argument focuses on the pragmatic question of how a military presence at a disaster site contributes to overcoming the devastating consequences of the disaster. Proponents of this argument argue that large-scale disasters overwhelm civilian 
capabilities; therefore military engagement is a conditio sine qua non of effective disaster management. People are affected and require assistance; infrastructure is devastated and needs to be repaired; and homes are destroyed and need to be rebuilt. Hence, it makes sense to turn to a military structure that can provide aid through the application of its manpower, expertise, resources, and assets.

The rejection-isolation argument calls for the military to play only a passive role in disaster management. Its proponents argue that providing relief to society in the case of a disaster distracts the military from its primary purpose. They argue that disaster relief reduces an army's capacity for combat missions and in its fight against terrorism. They also request a fair division of labour that would not overburden the military. The rejection-isolation argument could be also used in cases where even receiving countries impose restrictions on the delivery of military humanitarian assistance, either because they fear a foreign military presence on their own territory, or they are too proud to admit they need extensive international (military) assistance. As a consequence, the military can be seen to become isolated from society while the country becomes isolated from the international community.

\section{An Analyses of Selected Disasters}

Having examined the key theoretical arguments for military deployment in disaster response, we will now attempt to detect the presence of these arguments in some of the reported cases of predominantly natural disasters that occurred in the world during the period 2002-2011. In Table 2, we present the cases which form the core empirical framework of our secondary analysis in order to demonstrate the scope of problem faced by both state authorities and the crisis management structures when a large-scale disaster occurs. Some of the cases selected were so devastating that they required the engagement of all available national and international disaster management resources in order to cope with the consequences, and to normalise life following the disaster. 
Table 2: The Primary Consequences of Recent Large-scale Disasters ${ }^{\mathrm{vi}}$

\begin{tabular}{|c|c|c|c|}
\hline DISASTER & DEATH TOLL & OTHER VICTIMS & MATERIAL DAMAGE \\
\hline $\begin{array}{l}\text { Earthquake and } \\
\text { tsunami in SouthEast } \\
\text { Asia, December } \\
2004\end{array}$ & $\begin{array}{l}226,000 \text { (166,000 in } \\
\text { Indonesia, } \\
38,000 \text { in Sri } \\
\text { Lanka, 16,000 in } \\
\text { India, 5,300 in } \\
\text { Thailand and 5,000 } \\
\text { foreign tourists) }\end{array}$ & $\begin{array}{l}\text { over half a million } \\
\text { injured, while the } \\
\text { total number } \\
\text { affected was } \\
\text { estimated to run to } \\
5 \text { million }\end{array}$ & $\begin{array}{l}\$ 9.9 \text { billion; huge long-term } \\
\text { economic impact }\end{array}$ \\
\hline $\begin{array}{l}\text { Hurricane Katrina in } \\
\text { the US, August, } 2005\end{array}$ & 2,000 & $\begin{array}{l}\text { hundreds of } \\
\text { thousands of } \\
\text { evacuees widely } \\
\text { displaced }\end{array}$ & $\$ 80$ billion \\
\hline $\begin{array}{l}\text { Earthquake in } \\
\text { Pakistan in October, } \\
2005\end{array}$ & 88,000 & 100,000 injured & $\begin{array}{l}\text { enormous devastation in the } \\
\text { regions of Azad Jammu and } \\
\text { Kashmir }\end{array}$ \\
\hline $\begin{array}{l}\text { Earthquake in } \\
\text { Indonesia, May, } 2006\end{array}$ & 5,749 & $\begin{array}{l}38,000 \text { injured, } 1.2 \\
\text { million homeless; } \\
\text { in total } 2 \text { million } \\
\text { affected }\end{array}$ & $\begin{array}{l}600,000 \text { homes damaged or } \\
\text { destroyed }\end{array}$ \\
\hline $\begin{array}{l}\text { Cyclone Nargis in } \\
\text { Myanmar, May } 2008\end{array}$ & $\begin{array}{l}84,500 \text { and } 53,800 \\
\text { reported missing }\end{array}$ & 2.4 million affected & $\begin{array}{l}37 \text { townships significantly } \\
\text { affected }\end{array}$ \\
\hline $\begin{array}{l}\text { Sichuan Earthquake in } \\
\text { China, May } 2008\end{array}$ & $\begin{array}{l}\text { almost } 90,000 \text { were } \\
\text { counted as dead or } \\
\text { missing and } \\
\text { presumed dead }\end{array}$ & $\begin{array}{l}\text { nearly } 375,000 \\
\text { injured }\end{array}$ & $\$ 86$ billion \\
\hline
\end{tabular}




\begin{tabular}{|c|c|c|c|}
\hline $\begin{array}{l}\text { Earthquake in Haiti, } \\
\text { January } 2010\end{array}$ & 220,000 & $\begin{array}{l}300,000 \text { injured, } 3.5 \\
\text { million affected, } \\
1.5 \text { million } \\
\text { homeless }\end{array}$ & $\begin{array}{l}188,383 \text { houses badly damaged } \\
\text { and } 105,000 \text { destroyed }\end{array}$ \\
\hline $\begin{array}{l}\text { Floods in Pakistan, } \\
\text { July and August, } \\
2010\end{array}$ & $1,200-2,200$ & $\begin{array}{l}20 \text { million, millions } \\
\text { vulnerable to } \\
\text { malnutrition and } \\
\text { waterborne disease, } \\
14 \text { million homeless }\end{array}$ & $\begin{array}{l}\text { destroyed homes ( } 1.6 \text { million } \\
\text { houses), crops, and } \\
\text { infrastructure }\end{array}$ \\
\hline $\begin{array}{l}\text { Complex crisis in } \\
\text { Japan, March } 2011 \\
\text { (earthquake, tsunami, } \\
\text { nuclear disaster) }\end{array}$ & 18,500 & $\begin{array}{l}\text { half a million } \\
\text { evacuated }\end{array}$ & $\begin{array}{l}\$ 235 \text { billion (whole cities and } \\
\text { villages completely devastated) }\end{array}$ \\
\hline
\end{tabular}

Data sources: Pickrell (2005); Hurricane Katrina; the 2006 earthquake in Indonesia; Myanmar: Cyclone Nargis 2008 Facts and Figures (2011); the 2005 earthquake in Kashmir; the 2008 earthquake in Sichuan; the Pakistan Floods of 2010; IRIN (2006); Haiti Earthquake Facts and Figures; Oskin (2013);

The US military has increasingly assumed the role of a disaster response agency both at home and abroad, mostly in large-scale disasters. As a result, it has become an important player in national and international disaster response (Kapucu, 2011: 8). Perry and Travayiakis (2007: 32) analysed US military support for foreign disaster relief and humanitarian assistance in general, and they present their findings from the perspective of the utilitarian argument as a part of 'America's diplomatic repertoire.' They regard the engagement of US military capabilities abroad as disaster diplomacy that serves to support US strategic interests. The authors warn that critical military assets must not be diverted from the primary combat missions (the rejection-isolation argument), and that the appropriate division of labour should also be 
achieved between military and non-military disaster responders, as well as between national and international players.

Amundson et al. (2008: 236) interpret that the US military response to the tsunami in SouthEast Asia in 2004, the 2005 earthquake in Pakistan, and the 2006 earthquake in Indonesia through the framework of the utilitarian argument. They acknowledge that international civilian agencies and NGOs have traditionally been the primary responders to people affected by disasters; however, in the recent past, combined civilian and military operations have become increasingly frequent. As far as the US is concerned, this is due to the Department of Defence's policy on international operations, which have been 'extremely effective at improving the status and acceptance of the US and its military worldwide' (ibid.). Polls conducted following the US military assistance during the tsunami in South-East Asia and the earthquake in Pakistan showed a significant increase in positive sentiments towards the US among both the Indonesian and Pakistani population. There is also the added benefit of establishing useful contacts between the US military officers involved in the operation and the representatives of other militaries, local and international officials, and other stakeholders.

Brattberg (2013) also shares the belief that disaster relief boosts American soft power diplomacy throughout the world by presenting the US as a 'global force for good' (the utilitarian argument) which should not be underestimated. This would appear to be especially important given the erosion of US influence in the Asia-Pacific region and the growing influence of China. Additionally, military engagement in disaster relief may contain the negative consequences of major disasters and prevent the crisis from spilling across borders. This is especially true in the case of contagious diseases and the refugee flows that follow disasters. Military assistance could also improve relations and build trust with other militaries (security-strategic argument). Ultimately, by collaborating on disaster relief in other countries, the US has made itself 'an indispensable country' with a military that is capable of performing large-scale and complex relief operations (ibid.). 
In his analysis, Tritten (2013) observes the recent US foreign disaster relief through the lenses of both the functional-humanitarian and security-strategic arguments: for the afflicted countries, disaster relief means the provision of support to the affected people; for the US, it represents an opportunity for leverage and influence overseas. Humanitarian aid is regarded as 'a way to cement key relationships', especially in the typhoon- and earthquake-prone Pacific area. ${ }^{\text {viii }}$

The US Department of Defence decided to form a specialised unit that would be trained to provide prompt assistance in national disasters (Morrisey, 2008). Sceptics perceived this process to be a 'creeping militarism' of civilian culture and the erosion of the Posse Comitatus Act which has prevented the President from using the military in law enforcement within the US since 1878. The majority of US citizens have always opposed military involvement in civilian affairs. Therefore, the militarisation argument was developed in order to describe the process of training the military exclusively for disaster response purposes. The attempt by the George W. Bush administration to overlook the abovementioned Act as part of the war on terrorism exacerbated those fears. This was followed by the systemic and organisational changes of FEMA which became part of the Homeland Security Department in 2003, and which many feared became less relevant, less focused on disasters and more on terrorism, and a 'weak sister of the military.'

The attempted militarization of disaster relief in the wake of Hurricane Katrina in the US in 2005 was also questioned by Bay (2005) and Chossudovsky (2005). According to Bay, President Bush asked whether a natural disaster of a certain size would enable the Department of Defence to become the lead agency in coordinating and managing the response effort. He was not alone in thinking that such a move could improve disaster response. However, many warned of the subsequent militarisation and centralisation that are limited by law (Posse Comitatus Act, the Stafford Act). Chossudovsky believes that the Bush administration misused major disasters to justify a greater role for the military in civilian affairs. The Katrina fiasco 
triggered several comparisons between disasters and terrorism or between disasters and war, which led to the conclusion that the military should receive first-responder status. This was also introduced into crisis management documents and is supported by some media. Chossudovsky (ibid.) believes that the militarisation of emergency procedures is 'a done deal'. Additionally, this militarisation extends into civil society relief organisations. Although the procedures to engage the military in disaster relief are firmly fixed in law, there is a danger, warns Chossudovsky, that the Administration could use a national disaster as a pretext 'for introducing martial law and suspending constitutional rights'.

The Canadian experience in assisting Haiti following the devastating earthquake that hit the country in 2010 also deserves a mention. The argument for deploying civilian and military forces was a functional-humanitarian one with an element of utilitarianism in the aspiration. Canada's timely and comprehensive intervention, the efficiency of its response, and the evident impact of its financial contributions, resources and personnel clearly made a difference on the ground and substantially improved Canada's image abroad (Mamuji, 2012:

208). As Mamuji (2012: 220) indicates, the country's aid objectives have moved from 'humane internationalism', in which the altruistic provision of assistance and the interests of the receiving party had been crucial, towards 'international realism', in which national diplomatic, trade, and security gains have become predominant. In spite of the strong public support for the operation at home, some experts questioned Canada's increasing military involvement in disaster management that could result in 'heightened political control over the provision of disaster-relief, particularly demonstrated through the relationship between politics and the media (the militarisation argument)' (Mamuji, 2012: 219-220). ${ }^{\text {ix }}$

Experts in other countries also took up the issue. Gautam (2013), discussing the matter through the framework of the functional-humanitarian argument, is pragmatic in observing the role of India's military in disaster relief. The military should be a second responder to natural disasters, applying the principle: 'last to enter and first to leave'. In practice, this rarely holds due to the 
often ill-preparedness of civil administration to provide an effective response. Gautam (ibid.) emphasises the need for the military to achieve greater operational capability: In several cases the military had not been well enough prepared nor adequately equipped to deal with natural disasters.

The 2005 earthquake in Pakistan revealed the country ill-prepared for a disaster of this magnitude, having no mechanism for effective disaster preparedness and no governmental instrument (department or agency) dedicated to disaster response (IRIN, 2006). The Pakistan Government took the logical step of mobilising the military to perform disaster response and appointed an army general to manage the effort. The military was evidently the only organised force in the country that could provide the necessary assistance in a crisis. However, the International Crisis Group was critical of the military, arguing that the military machine that led the national and international relief work deliberately bypassed and disempowered civilian structures and the civilian administration in the affected areas (the militarisation argument). However, the already limited civilian structures had been damaged, paralysed, and even destroyed by the disaster, and were therefore unable to provide any effective disaster management.

The 2004 tsunami in South-East Asia, the 2005 Hurricane Katrina in US, the 2008 earthquake in Sichuan, China, the 2010 earthquake in Haiti, and the 2010 floods in Pakistan all confirmed the increasing role of the various militaries in responding to natural disasters (Madiwale and Virk, 2011: 1086). The reasons behind such developments were an increase in the incidence and scale of natural disasters - a concurrent trend towards the militarisation of humanitarian response to conflict situations - and an increased interest in disaster response on the part of militaries (the militarisation argument). The latter is a consequence of the desire to improve the military's public perception, staff morale, training, opportunities, and therefore treat humanitarian operations as a means for the armed forces to diversify their roles and expertise (the utilitarian argument). 
Drawing on the experience of the 2010 floods in Pakistan, Madiwale and Virk (ibid.) argue that the military can play a vital role in disaster response and that this view is widely held by the international humanitarian community. The military's contributions to disaster relief include: search and rescue capacities, logistical support, expertise, material resources for infrastructure projects, and trained manpower (the functional-humanitarian argument). However, humanitarian workers express regular concern that their core principles - impartiality, neutrality, and independence - could be challenged by a military presence. As a consequence, the security and action of humanitarian agencies could be jeopardised (the militarisation argument).

The engagement of Japanese Defence Forces (JDF) in Aceh, Indonesia, after the tsunami that hit South-East Asia in December 2004 is also noteworthy (Arcala Hall, 2008: 383). Japan's role as an aggressor during the Second World War meant that the deployment of its military overseas was a sensitive matter, although the JDF increasingly collaborate in a variety of 'nonuse-of-force missions'. Since it is expected that in a disaster relief operation the military will perform civilian tasks (policing, relief provision, post-conflict reconstruction, civil administration, etc.), a foreign military presence may be regarded with some concern by the receiving countries. Arcala Hall (2008: 384) thinks that the 'militarisation' of civilian functions might also set the armed forces in direct competition with international humanitarian agencies and NGOs. The interface between civilian and military structures thus crosses borders and functions, while the rules of engagement are still being formalised. The cost-benefit issues of overseas troop deployment and the sensitivities of the receiving countries to a foreign military presence on their soil must also be taken into account.

In reference to the above case, Arcala Hall (2008: 395) makes the following security-strategic argument: how can the authorities of the recipient country allow a foreign military presence within their territory without compromising their sovereignty? By contrast, the sending country's rationale (in this particular case Japan) can be explained by the utilitarian argument: 
deployment is a foreign policy decision based on the calculation of a gain in international prestige against the costs of deployment. The latter should not be overlooked due to the fact that, as a rule, foreign military support is requested only in extraordinary circumstances in which heavy logistics and a large ground force are required. In the case of Japan, we could perhaps add a further security-strategic argument, namely that US policy actually encourages Japan to be more active in the region and to assume greater responsibility for its security, meaning that by taking an active role in regional disaster response Japan potentially improves its security relations with the US.

Barber (2009) also raises an important point of international law with regard to those countries that reject foreign disaster assistance (the rejection-isolation argument), as Myanmar did during cyclone Nargis in 2008. The government of Myanmar imposed significant restrictions on the delivery of humanitarian aid which triggered a debate as to whether international actions have a 'responsibility to protect' populations from the bad policy decisions of their governments in a disaster. It was suggested that the legal doctrine could be invoked to justify military intervention for the purpose of delivering humanitarian aid to the survivors of the cyclone. An analysis of customary international law revealed that, in this particular case, the restrictions imposed by the Myanmar government were not so strict as to justify military intervention. The Intertect Study (1989) addressed the similar issue of crisis victims' 'right to assistance': some experts have argued that military forces representing the international community should provide safe passage for relief commodities and personnel without the consent of the affected country.

\section{Discussion and Conclusions}

Our analysis of the theoretical considerations of military deployment in disaster response reveals that the arguments most frequently invoked in the discourse are the utilitarian, securitystrategic, militarisation, functional-humanitarian, and rejection-isolation arguments. However, 
an empirical review of actual military disaster responses reveals which of these arguments are most frequently invoked in real-life scenarios. It would be impossible to perform an exact statistical analysis of the various arguments, nevertheless recent practice would seem to confirm that the militarisation argument is most popular, followed by the utilitarian argument. The latter does not advocate the engagement of the military in disaster response on the basis of the needs of the affected population, but rather on the basis of the benefits accruing to the states and institutions (the military) that offer such assistance. The former warns that an increased military presence in disaster management may threaten the operating principles of civilian agencies and humanitarian organisations and may lead to their gradual replacement with military structures. These two arguments are followed by the functional-humanitarian and security-strategic arguments. The former is predominantly concerned with the affected population, their property and infrastructure, and instead regards the military an actor that is capable of significantly contributing to the more rapid and effective management of the post-disaster situation. The latter addresses the question of how military assistance could improve international security by reinforcing strategic relations between states. The rejection-isolation argument is the least present in the analysis and is sceptical of the use of the military in disaster response due to a concern that its capabilities will be diverted from its primary duties, such as combat and counterterrorism. Our analysis of the arguments reveals a lively debate on the role of the military in disaster management. However, somewhat surprisingly, the needs of the disaster-stricken population do not necessarily assume primary importance in this debate.

We have therefore answered the first research question concerning the identity of the primary theoretical arguments, so let us turn to second question, whether these arguments can predict the characteristics of civil-military relations in disaster management. Taking into account the characteristics of disasters and the legal bases for military engagement, the nature of the arguments and the motives behind them do predict the characteristics of civil-military relations in disaster management to a certain degree. Utilitarian and security-strategic arguments 
emphasise the important benefits to the political establishment and the military; the benefit to the affected population, the civilian search and rescue teams, and the humanitarian organisations is of secondary importance. Consequently, we might expect friction between the various military and civilian crisis management actors. The militarisation argument puts pressure on civil-military relations. This pressure comes from the civilian and humanitarian side, especially when the civilian structure capabilities for managing the disaster are low and the readiness of the civilian disaster management structures to accept military assistance is also low. This anticipates potential problems. The rejection-isolation argument could create conflict between a military that is reluctant to engage in disaster management, and civilian authorities and the public who want it to engage. The functional-humanitarian argument on the other hand foresees a certain degree of harmony in civil-military relations because it best serves the interests of all the stakeholders involved. This is especially true when the military's operational preparedness to engage in disaster management is high and when the general public also have high expectations of the military's ability to perform well in a disaster management situation.

Our analysis serves as a comprehensive review of the arguments concerning military engagement in disaster management and considers some of the possible impacts they may have on the development of civil-military relations in the specific circumstances of disaster management. However, our work marks only the beginning of research. Subsequent studies might consider addressing the following six issues which we have raised. (1) The fact that some stakeholders in disaster management fear a military presence, while admitting that military assistance is required due to the skills, equipment, and resources that it can provide. (2) Despite the fact that the role of the armed forces in providing disaster assistance is a legal duty, its level of operational preparedness to act effectively in disaster management is rather limited. (3) Even if military commanders were better prepared (specialised units, training, planning and better collaboration with civilian structures), there remains a general fear in disaster-management circles of a militarisation of disaster response. (4) On the one hand, the military perceives 
disaster management as an opportunity to improve their image and legitimacy, and on the other, they worry that disaster response engagement might hamper the effectiveness of their other duties (combat missions, fighting terrorism, peace operations, etc.). (5) Civilian disaster management structures require military assistance in cases where they are overwhelmed by the scope and severity of the disaster, yet at the same time they compete with military structures (disaster as an opportunity) and fear the predominance of military structures in their sphere. They also fear that their culture and values may become 'contaminated' if they were to frequently collaborate with the military. 6) Civilian and military disaster management structures are forced to collaborate in disaster response, but they do not invest enough will and energy in improving coordination, common planning, training, standardising equipment where possible, nor in the development of civil-military cooperation best practice.

Future research should be directed towards resolving the above mentioned tensions between and within the civilian and military structures in order to improve both national and international disaster management response to the ever increasing and intensifying phenomenon of disasters. 


\section{Bibliography:}

Amundson D, Lane D, Ferrara E (2008) Operation Aftershock: The U.S. Military Disaster Response to the Yogyakarta Earthquake May through June 2006. Military Medicine 173: $236-240$.

Arcala HR, Cular A (2010) Civil-military Relations in Disaster Rescue and Relief Activities: Response to the Mudslide in Southern Leyte, Philippines. Scientia Militaria. South African Journal of Military Studies 38(2): 62-88.

Arcalla HR (2008) Civil-military Cooperation in International Disaster Response: The Japanese Self-Defence Forces' Deployment in Aceh, Indonesia. The Korean Journal of Defense Analysis 20(4): 383-400.

Armitage RL, Nye JS (2008) Implementing Smart Power: Setting an Agenda for National Security Reform. Washington DC: Center for Strategic \& International Studies.

Barber R (2009) The Responsibility to Protect the Survivors of Natural Disasters: Cyclone Nargis, a Case Study. Journal of Conflict and Security Law 14(1): 3-34.

Bay, A (2005) Military and Natural Disasters. Available at: http://www.startegypage.com/on_point/2005928.aspx (accessed 1 July, 2014).

Boëne, B (1990) How Unique Should the Military be? A Review of Representative Literature Outline of Synthetic Formulation. European Journal of Sociology, 31(1): 3-59.

Born H, Haltiner KW, Malesic M (Eds.) (2004) Renaissance of Democratic Control of the Armed Forces in Contemporary Societies. Baden-Baden: Nomos.

Brattberg E (2013) The Case of US Military Response during International Disasters. Available at: http://thehill.com/blogs/congress (accessed 30 May, 2014).

Briggs CM (2012) Climate Security, Risk Assessment and Military Planning. International Affairs. 88(5): 1049-1064. 
Chossudovsky M (2005) Natural Disasters and the Militarization of America. Global Research. Available at: http://www.globalresearch.ca (accessed June 27, 2014).

Civil-Military Relations in Disaster Response. Available at: http://www.disastergovernance.net/study_groups/civil_military_relations/ (accessed June 27, 2014).

Cohn, L (2003) Civil-Military Relations in the U.S. In Callaghan, J, Kernic, F (Eds.) (2003):

Armed Forces and International Security. Global Trends and Issues. Münster: LIT, 65-72.

CRED (2012) Annual Disaster Statistical Review 2012. The Numbers and Trends. Brussels:

Center for Research of Epidemiology and Disasters; Institute of Health and Society.

Université Catholique de Louvain.

Croissant A, Kuehn D (2011) Introduction: New Perspectives on Civil-Military Relations. European Political Science 10 (2): 131-136.

Dandeker, C (2000) New Times and New Patterns of Civil-Military Relations. In Kuhlmann, J, Callaghan, J (Eds.) Military and Society in $21^{\text {st }}$ Century Europe. A Comparative Analysis. Münster: LIT, 27-43.

Etkin D, McBey K, Trollope C (2011) The Military and Disaster Management: A Canadian Perspective on the Issue. Available at: http://www.crhnet.ca/sites/default/files/library/Etkin.pdf (accessed 25 May, 2014).

Feaver PD, Kohn RH (2001) Soldiers and Civilians: The Civil-Military Gap in American National History. Cambridge: MIT Press.

Ferris E (2012) Future Directions in Civil-Military Responses to Natural Disasters.

Washington DC: Brookings paper.

Fischer E (2011) Disaster Response: The Role of a Humanitarian Military. Available at: army-technology.com (accessed 26 June 2014). 
Forster A (2002) New Civil-Military Relations and its Research Agendas. Connections 1(2): $71-88$.

Freistein, K (2011) An Introduction to the Analysis of Discourse in Civil-Military Relations Research. European Political Science 10 (2): 167-175.

Freundenburg, WR (1997) Contamination, Corrosion and Social Order: An Overview. Current Sociology 45 (3): 19-39.

Futamura M, Hobson C, Turner N (2011) Natural Disasters and Human Security. Available at: http://unu.edu/publications/articles/natiral-disasters-and-human-security.html (accessed 29 May, 2014).

Gautam PK (2013) Role of Indian Military in Disasters. Available at: http://www.idsa.in/idsacoments/ (accessed 20 July, 2014).

Haiti Earthquake Facts and Figures. Available at: http://www.dec.org.uk/haiti-earthquakefactsand-figures (accessed 16 February, 2015).

Hänggi H (2004) Conceptualizing Security Sector Reform and Reconstruction. In Bryden A, Hänggi H. Reform and Reconstruction of the Security Sector, Münster: LIT, 3-18.

Hofmann CA, Hudson L (2009) Military Responses to Natural Disasters: Last Resort or Inevitable Trend? Humanitarian Exchange Magazine 44: 1-5.

Huntington, S (1957) The Soldier and the State. Cambridge, MA: Harvard University Press. IRIN. In-depth: When Disaster Strikes: The Response to the South-Asian Earthquake (2006). Humanitarian news and analysis. A service for the UN OCHA. Available at: http://www.irinnews.org/in-depth/34370/6/Pakistan (accessed 15 June, 2014). Indonesia earthquake 2006. Available at: http://www.redcross.org.uk/en/Whatwedo/Emergency-response/Past-emergency-appeals/Indonesia-earthquake-2006 (accessed 16 February, 2015). 
Intertect Relief and Reconstruction Corp. The History of Military-Assisted Humanitarian Aid (1989). Dallas.

Hurricane Katrina. Available at: http://www.history.com/topics/hurricane-katrina (accessed 16 February, 2015).

Oskin B (2013) Japan Earthquake \& Tsunami of 2011: Facts and Information. Available at: http://www.livescience.com/39110-japan-2011-earthquake-tsunami-facts.html Janowitz, M (1960) The Professional Soldier. Glencoe, IL: Free Press.

Kapucu N (2011) The Role of the Military in Disaster Response in the U.S. European Journal of Economic and Political Studies 4(2): 7-33.

Kashmir earthquake $2005 . \quad$ Available at: http://www.britannica.com/EBchecked/topic/1483628/Kashmir-earthquake-of-2005 (accessed 16 February, 2015).

Laksmana EA (2010) The Indonesian Defence Forces and Disaster Relief: Potential Pitfalls and Challenges. Singapore: S. Rajaratnam School of International Studies.

Madiwale A, Virk K (2011) Civil-military Relations in Natural Disasters: A Case Study of the 2010 Pakistan Floods. International Review of the Red Cross. 93(884): 1085-1105.

Malešič M (2014) Vloga vojske pri odzivanju na nesrečo: vsebina in narava argumentov. Teorija in praksa. (51)6: 1111-1130.

Mamuji A (2012) Canadian Military Involvement in Humanitarian Assistance: Progress and Prudence in Natural Disaster Response. Canadian Foreign Policy Journal 18(2): 208-224.

Marret JL (2009) Civil-Military Relations in Disaster Response. In Steets J and Hamilton DS Humanitarian assistance: Improving U.S.-European Cooperation. Baltimore: Center for Transatlantic Relations. Johns Hopkins University, 339-358. 
Morrisey S (2008) Should the Military Be Called in for Natural Disasters?. Time, December 31, 2008.

Moskos, CC, Williams, JA, Segal, DR. (Eds.) (2000) The Postmodern Military: Armed Forces After the Cold War. Oxford: Oxford University Press.

Myanmar: Cyclone Nargis 2008 Facts and Figures (2011). Available at http://www.ifrc.org/en/news-and-media/news-stories/asia-pacific/myanmar/myanmarcyclonenargis-2008-facts-and-figures/ (accessed 16 February, 2015).

Nielsen SC (2012) American civil-military relations today: the continuing relevance of Samuel P. Huntington's The soldier and the state. International relations 88 (2): 369-376.

Pakistan Floods of 2010. Available http://www.britannica.com/EBchecked/topic/1731329/Pakistan-Floods-of-2010 (accessed 16 February, 2015).

Perry C, Travayiakis M (2011) Reforming Military Support for Foreign Disaster Relief and Humanitarian Assistance. Liaison. A Journal of Civil-Military Humanitarian Relief Collaboration IV(1): $32-41$.

Pickrell J (2005) Facts and Figures: Asian Tsunami Disaster. Available at: http://www.newscientist.com/article/dn9931-facts-and-figures-asiantsunamidisaster.html\#.VOGyZOaG-Gw (Accessed 16 February 2015)

Pinch, F (2003) Recent Trends in Military Sociology in Canada. In Callaghan, J, Kernic, 8192.

Sarkesian SC. (1981) Beyond the Battlefield: The New Military Professionalism. New York: Pergamon.

Segal DR., Blair J, Newport F, Stephens S (1974) Convergence, Isomorphism, and 
Interdependence at the Civil-Military Interface. In Journal of Political and Military Sociology. 2 (Fall).

Sichuan earthquake of 2008. Available at:

http://www.britannica.com/EBchecked/topic/1436631/Sichuanearthquake-of-2008 (accessed 16 February, 2015).

SIPRI (2008) The Effectiveness of Foreign Military Assets in Natural Disaster Response.

Stockholm: SIPRI.

Tatham P, Oloruntoba R, Spens K (2012) Cyclone Preparedness and Response: An Analysis of Lessons Identified Using an Adapted Military Planning Framework. Disasters 36(1): 54-

82.

Tritten TJ (2013) When Disaster Strikes, US Military Assets Often Key to Relief Efforts.

Stars and Stripes. Available at: http://www.stripes/com/news (accessed 20 June 2014).

van der Meulen, J (2003) Public Opinion and the Role of the Media. In Callaghan J, Kernic

F, 299-302.

Weeks MR (2007) Organizing for Disaster: Lessons from the Military. Business Horizons 50

(6): 479-489.

\footnotetext{
${ }^{\mathrm{i}}$ A disaster is included in the database if one of the following criterion is met: more than 10 people are reported dead; more than 100 people are reported affected; a declaration of a state of emergency; or a call for international assistance (CRED, 2013: 7). "ii For example, UNOCHA (Office for the Coordination of Humanitarian Affairs), the EU Civil Protection Mechanism and NATO’s Civil Emergency Planning.

iii Freudenburg (1997: 19, 20) argues that the history of disaster research began when military planners began to consider ways in which communities might respond to nuclear attack. Although this argument is disputable, it is now evident that various natural, technological and man-made disasters attract the attention of researchers. The focus has profoundly changed.

iv Forster (2002) called upon researchers to be more theoretically and methodologically courageous in overcoming the traditional approaches.

$\checkmark \quad$ It is worth mentioning that when peacekeeping became a predominant duty of the armed forces after the Cold War, scholars noticed its impact on civil-military relations, especially on the legitimacy of the armed forces

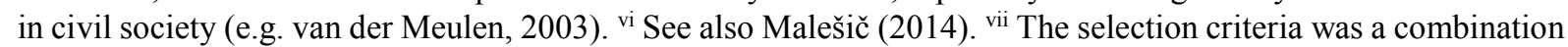
of there being a sizeable disaster plus the major involvement of the military in the disaster management.
} 
The operation for US military assistance to Japan during the earthquake, tsunami, and nuclear disaster in 2011 was named Tomodachi (Friend).

ix The research carried out in Ontario among civilian crisis managers revealed that the latter were slightly more opposed to the militarisation of the crisis response (the presence of the military in the process) than they were opposed to their own militarisation (civilian organisations following a military model) (Etkin et al., 2014: 14). 